\title{
Two Cases of Lung Carcinoma with Osteoplastic Bone Metastasis
}

\author{
Takashige MiyazaKi, Shigeru Kohno**, Akira SAKamoto, Kiyotaka Komori, \\ Kenji KumagaE*, Kohei Hara** and Masao KishiKawA***
}

Two cases of lung carcinoma with osteoplastic bone metastasis are reported. The bone roentgenogram of a 66-year-old woman with pleuritis carcinomotosa revealed multiple sclerotic changes in the right forearm, lumbar spine, and pelvis. Biopsy at internal fixation of the left humerus revealed metastatic adenocarcinoma with osteoplastic change. In a 77-year-old man with small cell carcinoma of the lung, after chemotherapy, osteoplastic bone changes were detected in roentgenograms. An ivory vertebra formation was seen in $\mathrm{L} 1, \mathrm{~L} 2$ and $\mathrm{L4}$, and bone scintigram showed, additionally, uptake in the ilium.

(Internal Medicine 32: 416-420, 1993)

Key words: adenocarcinoma, small cell carcinoma, bone scintigram

\section{Introduction}

Metastasis to bone is not uncommon with lung cancers. In the literature, the incidence of bone metastasis varies from 15.7 to 51 percent $(1,2)$. Whereas the incidence of osteolytic metastasis is frequent, osteoplastic bone lesions are rare (3-11). We present here two cases of osteoplastic bone metastasis from bronchogenic carcinoma.

\section{Case Report}

Case 1

A 66-year-old woman was admitted to our hospital with a three-month history of right forearm pain and swelling; she also had right iliac pain. She had no cough, dyspnea, or cyanosis. She had been in good health, and her past medical history was unremarkable, except for hysterotomy because of uterine myoma. She was a non-smoker. There was no family history of neoplasms. Physical examination showed a fairly well nourished woman, whose right forearm was swollen with slight tenderness. Decreased breath sounds were audible over the left posterior lower chest. An enlargement of the thyroid gland, lymphadenopathy and hepatosplenomegaly were absent. The neurologic findings were normal except for decreased deep tendon reflexes.

A chest roentgenogram revealed a large left pleural effusion
(Fig. 1). Cytology of the effusion showed an adenocarcinoma. Chest CT scan after thoracic drainage revealed a nodule, $2.0 \mathrm{~cm}$ in diameter, with spiculated, irregular margins in the left posterior basal segment, and invasion of mediastinal lymphnodes (Fig. 2). Retrospectively, the nodule was identified in a screening chest roentgenogram of two years previously; the nodule had increased slightly in a roentgenogram of one year later.

Laboratory investigation revealed an erythrocyte sedimentation rate of $78 \mathrm{~mm}$ in the first hour. The hemoglobin was 13.2 $\mathrm{g} / \mathrm{dl}, \mathrm{WBC} 10,400 / \mathrm{mm}^{3}$ with $65 \%$ neutrophils, and platelets were $415,000 / \mathrm{mm}^{3}$. Fasting blood sugar was $202 \mathrm{mg} / \mathrm{ml}, \mathrm{HbA}_{\mathrm{l}}$ $13.3 \%, \mathrm{HbA}_{\mathrm{l}} \mathrm{c} 10.5 \%$, and urine sugar was $2.1 \mathrm{~g} / \mathrm{dl}$. Serum calcium and phosphorus levels were normal. Serum level of parathormone was $610 \mathrm{pg} / \mathrm{ml}$, and 1,25(OH) $)_{2}$ Vit.D, $33 \mathrm{pg} / \mathrm{ml}$. LDH was 1,298 IU/l, and alkaline phosphatase (ALP), 3,372 IU/l with $85 \%$ of $\mathrm{ALP}_{3}$ isozyme. CEA levels were $99.9 \mathrm{ng} / \mathrm{ml}$ in blood, and $42.3 \mathrm{ng} / \mathrm{ml}$ in the effusion, and neuron-specific enolase (NSE) was $13 \mathrm{ng} / \mathrm{ml}$.

Bone roentgenograms revealed multiple sclerotic changes, especially in the right forearm, lumbar spine, and pelvis (Fig. 3a and $3 \mathrm{~b}$ ). Bone scintigram also showed multiple uptake (Fig. 4). $\mathrm{CDDP}$ at $150 \mathrm{mg}$ and $\mathrm{OK} 432$ at $6.0 \mathrm{KE}$ were administered intrathoracically after thoracic drainage. While at home she experienced progressive anorexia and malaise. After four months, pathological bone fracture of the left arm was detected. Biopsy at internal fixation of the left humerus revealed

From the Departments of Internal Medicine, *Orthopedics, Isahaya Insurance General Hospital, Isahaya, **the Second Department of Internal Medicine, Nagasaki University School of Medicine, Nagasaki, and ***Department of Pathology, Data Center for Atomic Bomb Disaster, Nagasaki University School of Medicine, Nagasaki

Received for publication September 24, 1992; Accepted for publication April 9, 1993

Reprint requests should be addressed to Dr. Kohei Hara, the Second Department of Internal Medicine, Nagasaki University School of Medicine, 1-7-1, Sakamoto, Nagasaki 852, Japan 


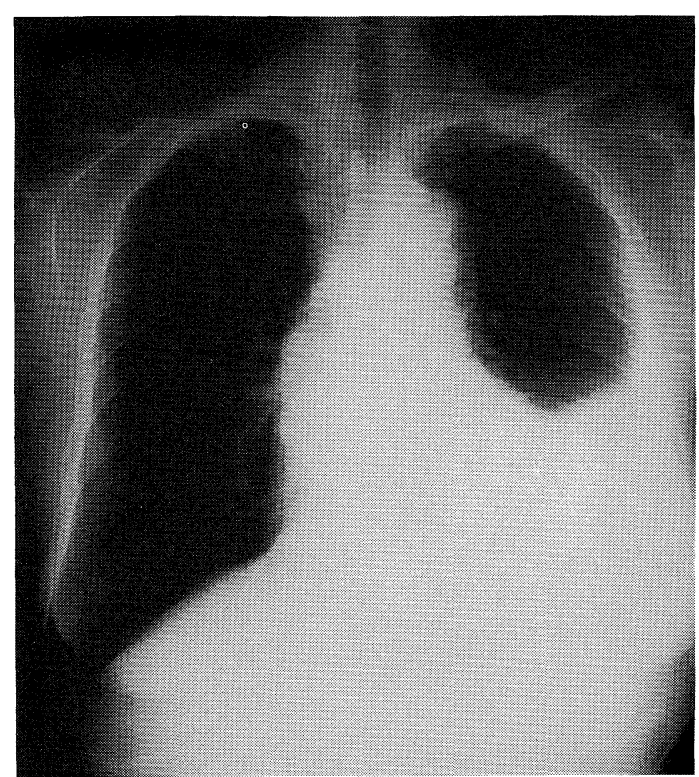

Fig. 1. Chest roentgenogram on admission (case 1). A large left pleural effusion was noted.

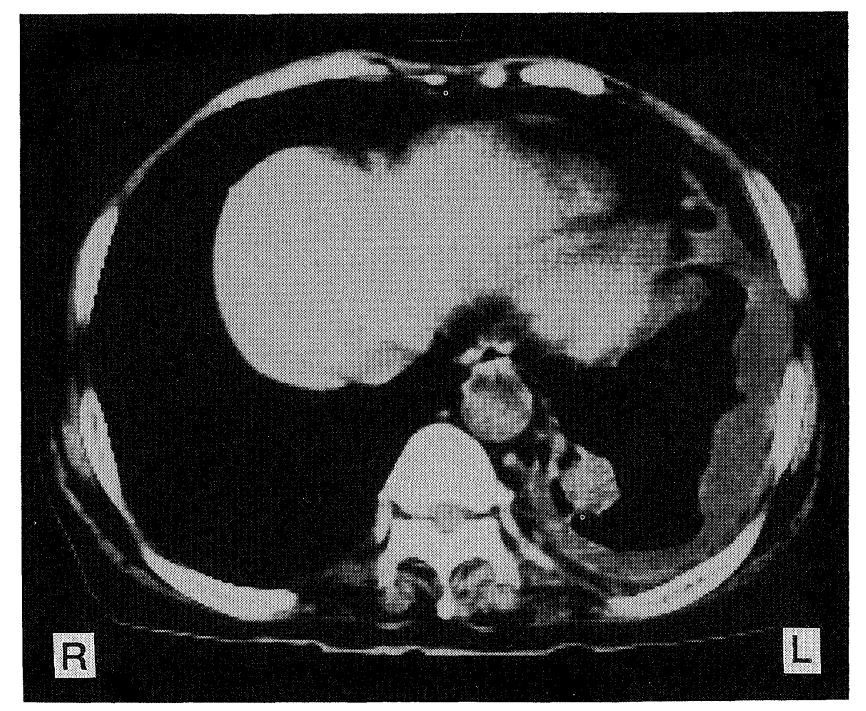

Fig. 2. A chest CT scan after thoracic drainage revealed a nodule, $2.0 \mathrm{~cm}$ in diameter, with spiculated, irregular margins, in the left posterior basal segment.

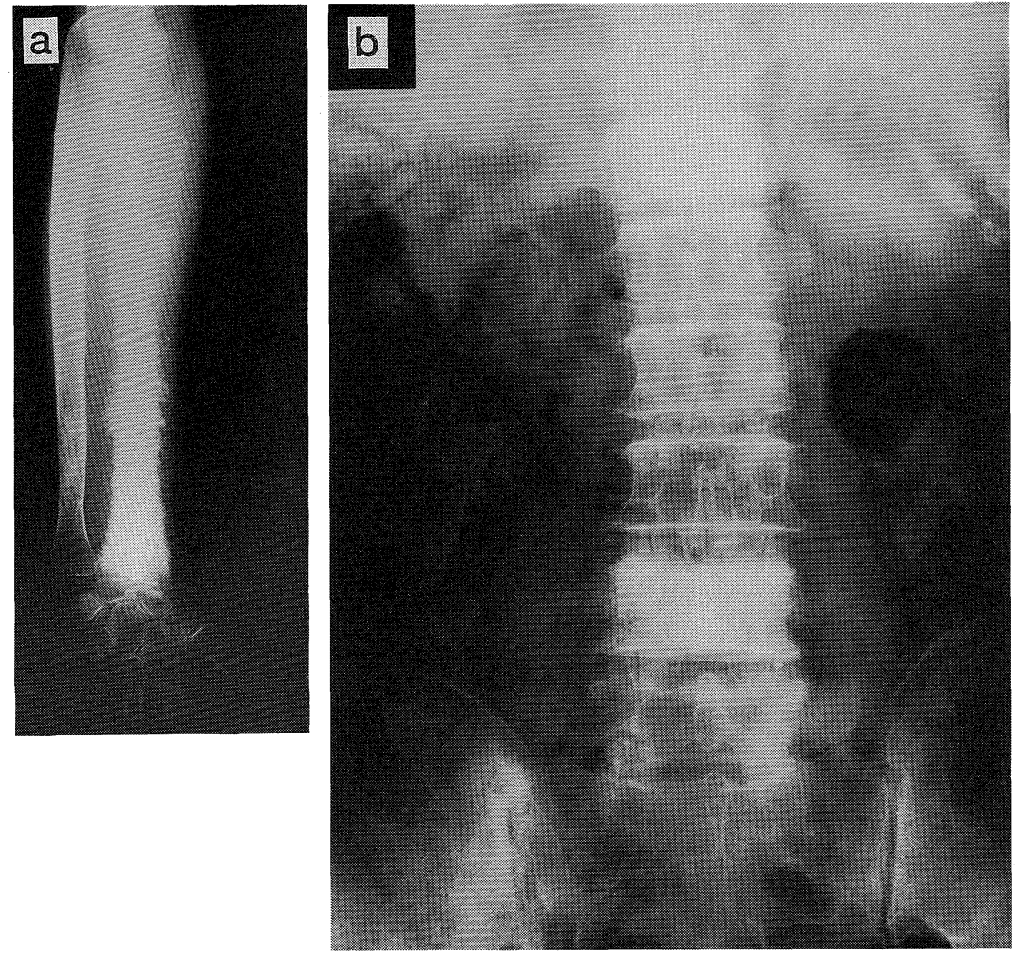

Fig. 3. Bone roentgenogram revealed sclerotic changes, especially in the right forearm (a). Spine (Th12 and L4), and right pelvis were also sclerotic (b).

osteoplastic bone metastasis (Fig. 5).

\section{Case 2}

A 77-year-old man was admitted to our hospital because of lumbago. His chest roentgenogram revealed a mass-like shadow in the left anterior basal segment (Fig. 6). The diagnosis of small cell carcinoma was made by aspiration lung biopsy. The NSE level was $40 \mathrm{ng} / \mathrm{ml}$. Before treatment, bone roentgenograms 


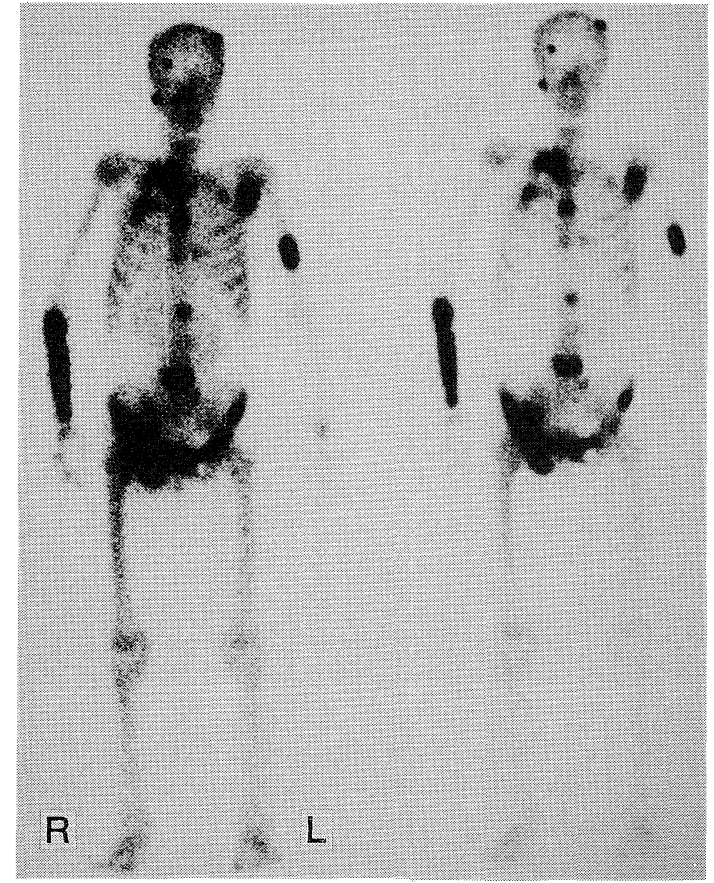

Fig. 4. A bone scintigram also showed multiple uptake.

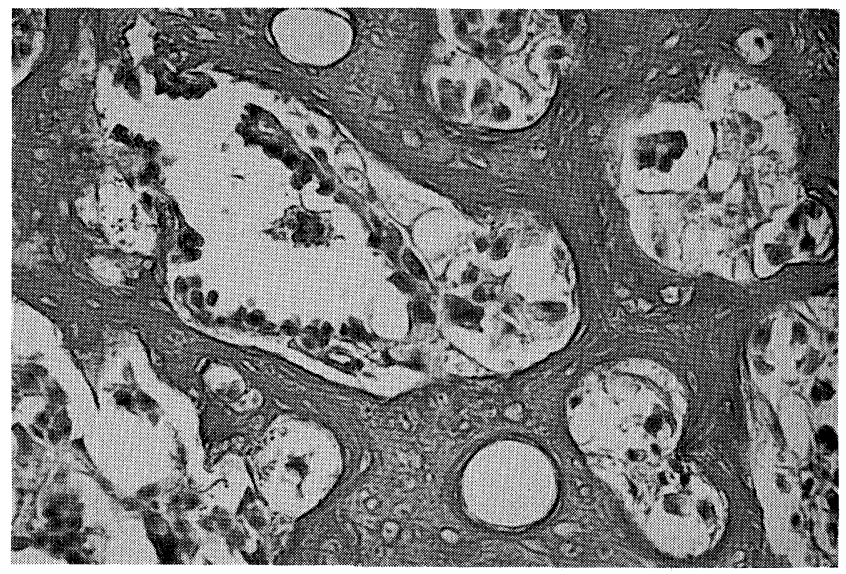

Fig. 5. Biopsy at internal fixation of the left humerus revealed osteoplastic bone metastasis (HE stain, $\times 200$ ).

were normal, but a bone scintigram showed multiple uptake in the spine (L4). As the possibility of bone metastasis was not ruled out, a combination chemotherapy of carboplatin and etoposide was performed. After four courses of chemotherapy, the mass-like shadow had almost disappeared, but osteoplastic changes were detected in roentgenograms. An ivory vertebra formation was seen in the L1, L2 and L4 (Fig. 7), and bone scintigram showed, additionally, uptake in the ilium (Fig. 8).

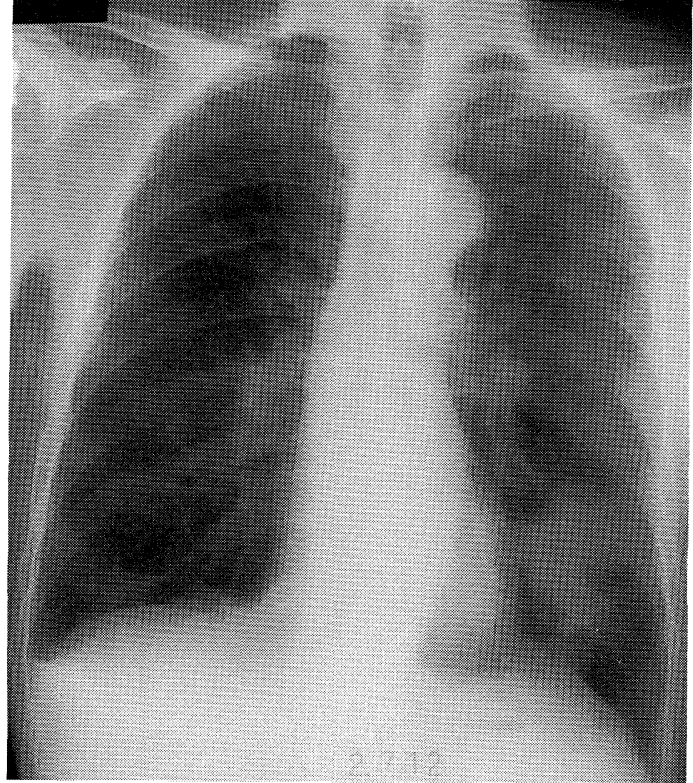

Fig. 6. Chest roentgenogram on admission (case 2). The chest roentgenogram revealed a mass-like shadow in the left anterior basal segment. The diagnosis of small cell carcinoma was made by aspiration lung biopsy.

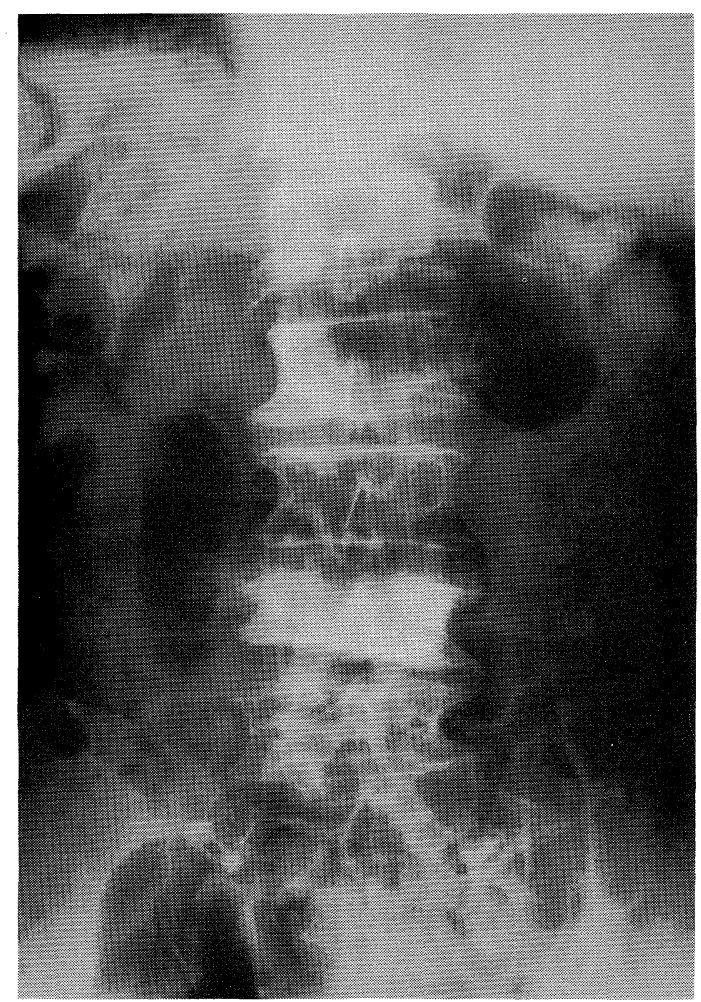

Fig. 7. Bone roentgenograms revealed osteoplastic bone changes. An ivory vertebra formation was seen in L1, L2 and L4. 

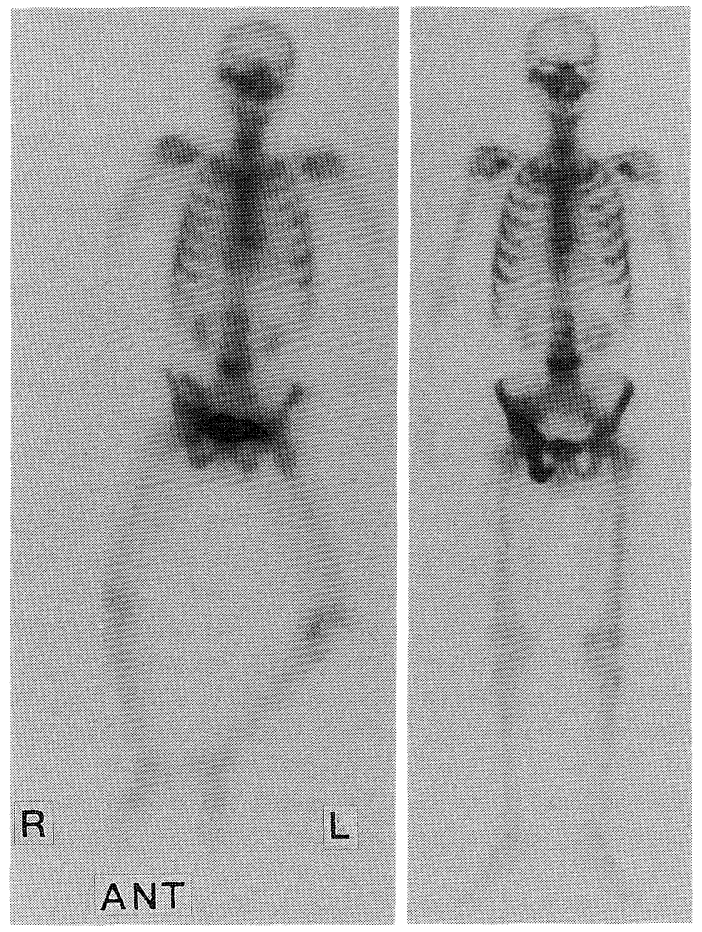

Fig. 8. Bone scintigram of case 2. Left (on admission), uptake in the spine (L4). Right (after four courses of chemotherapy), uptake in $\mathrm{L} 1, \mathrm{~L} 2, \mathrm{~L} 4$ and the right ilium.

\section{Discussion}

The rate of metastasis to bone has been shown at autopsy to be as high as 83.3 percent in prostate, 61.1 percent in breast, and 51.1 percent in lung cancer (1). In women, the most frequent origin of metastatic carcinoma is carcinoma of the breast, followed by carcinoma of the lung. In men, carcinoma of the lung is the most frequent cause of metastatic bone disease (1).

Tumor cells which enter the circulation are carried to the vascular bone marrow. This is followed by invasion of the bone tissue matrix, and finally by invasion of the cortical bone (12). It is known that bone itself contains growth factors and angiogenesis factors, such as fibroblast growth factor, plateletderived growth factor, transforming growth factor beta and insulin-like growth factors I and II, each of which is important for the local growth of the tumor (13). Although most carcinomas tend to cause osteolytic metastasis, prostate cancer and breast cancer occasionally provoke osteoplastic metastasis in the affected bone, producing an increase in osseous density on the radiograph. In prostate cancer extracts, osteoblast stimulatory factors were found which could be responsible for the stimulation of new bone formation (13).

Whereas osteolytic metastasis is frequent in lung cancers, 26 cases (including our two cases) of osteoplastic metastasis from primary bronchogenic carcinomas have been reported by several authors (3-11). Of these cases, 13 were adenocarcinomas, 9 were small-cell carcinomas, 3 were anaplastic, and one was a

Table 1. A Summary of Case Reports in the Literature of Lung Cancer with Osteoplastic Bone Metastasis

\begin{tabular}{|c|c|c|c|c|}
\hline Patient & Author & & Age and sex & Cell type \\
\hline 1 & Feld & & $56 \mathrm{M}$ & Adenocarcinoma \\
\hline 2 & Sackner & & $56 \mathrm{M}$ & Adenocarcinoma \\
\hline 3 & Beer & 1 & $37 \mathrm{M}$ & Anaplastic \\
\hline 4 & & 2 & $44 \mathrm{M}$ & Anaplastic \\
\hline 5 & & 3 & $53 \mathrm{M}$ & Adenocarcinoma \\
\hline 6 & & 4 & $48 \mathrm{M}$ & Adenocarcinoma \\
\hline 7 & & 5 & $61 \mathrm{M}$ & Adenocarcinoma \\
\hline 8 & Napoli & 1 & $51 \mathrm{M}$ & Small-cell \\
\hline 9 & & 2 & $59 \mathrm{M}$ & Small-cell \\
\hline 10 & & 3 & $41 \mathrm{M}$ & Adenocarcinoma \\
\hline 11 & & 4 & $47 \mathrm{M}$ & Small-cell \\
\hline 12 & & 5 & $58 \mathrm{~F}$ & Adenocarcinoma \\
\hline 13 & & 6 & $42 \mathrm{M}$ & Small-cell \\
\hline 14 & & 7 & $57 \mathrm{M}$ & Small-cell \\
\hline 15 & & 8 & $69 \mathrm{M}$ & Small-cell \\
\hline 16 & & 9 & $73 \mathrm{M}$ & Small-cell \\
\hline 17 & Kimoto & 1 & $25 \mathrm{~F}$ & Adenocarcinoma \\
\hline 18 & & 2 & $55 \mathrm{M}$ & Adenocarcinoma \\
\hline 19 & & 3 & $68 \mathrm{~F}$ & Anaplastic large cell \\
\hline 20 & & 4 & $59 \mathrm{M}$ & Anaplastic \\
\hline 21 & Araki & & $68 \mathrm{M}$ & Adenocarcinoma+hepatoma \\
\hline 22 & Itoh & & $62 \mathrm{M}$ & Small-cell (Oat cell) \\
\hline 23 & Ueno & & $56 \mathrm{~F}$ & Adenocarcinoma \\
\hline 24 & Matsumura & & $50 \mathrm{~F}$ & Adenocarcinoma \\
\hline 25 & Our case & 1 & $66 \mathrm{~F}$ & Adenocarcinoma \\
\hline 26 & & 2 & $77 \mathrm{M}$ & Small-cell \\
\hline
\end{tabular}


large-cell carcinoma (Table 1). It is notable that osteoplastic bone metastasis was not seen in squamous-cell carcinoma of the lung. Elaboration of a parathyroid hormone-related protein, which stimulates osteoclastic bone resorption in vitro and in vivo, was confirmed in a squamous-cell carcinoma of the lung (14). This fact leads one to speculate that the production of parathyroid hormone-related protein may account for the apparent lack of osteoplastic lesions in this tumor $(6,9)$. However, recent clinical studies of serum parathyroid hormone-related protein level in patients with lung cancer support the view that a wide variety of cell types can produce parathyroid hormonerelated protein (15). Histochemical study using anti-parathyroid hormone-related protein antibody also revealed that all lung cancer cell types produce parathyroid hormone-related protein (Sakamoto et al., unpublished observation). Nevertheless, further investigation is needed to determine whether parathyroid hormone-related protein molecule has not only immunologically reactivity but also biologically activity.

The roentgenographic appearance of the bone lesions in case 2 was indistinguishable from those due to metastasis from prostatic cancer. Histologic examination of the bone lesion was not performed, but a primary carcinoma of the prostate was considered unlikely based on the following findings: 1) normal size, shape and consistency of the prostate and 2) normal levels of serum acid phosphatase.

The treatment of skeletal metastasis from a primary lung cancer depends on the patient's general condition, the radiosensitivity of the lesion, the site and extent of the involvement, and the proximity of the tumor to vital organs such as the spinal cord. Most skeletal metastasis of pulmonary carcinomas are radiosensitive and a partial response can be achieved in some patients by radiation therapy $(1,2)$.

\section{References}

1) Matsubayashi T, Murata K, Ikeda T, Tadokoro K, Nishimaki H, Ohta A. The survival of cancer patients after radiotherapy for bone metastasis. Jpn J Radiol 48: 1523, 1988 (in Japanese).

2) Kawasaki M, Hara N, Ichinose $Y$, et al. Bone metastases of primary lung cancer. Lung Cancer 30: 359, 1990 (in Japanese).

3) Feld H, Olivetti RG. Occurrence of metastasis of bronchogenic carcinoma to bone; report of a case with osteoblastic metastasis. Am J Roentgenol 76: 81, 1956.

4) Sackner MA, Spivack AP, Balian LJ. Hypocalcemia in the presence of osteoblastic metastases. N Engl J Med 262: 173, 1960.

5) Beer DT, Dubowy J, Jimenez FA. Osteoblastic metastases from bronchogenic carcinoma. Am J Roentgenol 91: 161, 1964.

6) Napoli LD, Hansen HH, Muggia FM, Twigg HL. The incidence of osseous involvement in lung cancer, with special reference to the development of osteoblastic changes. Radiology 108: 17, 1973.

7) Kimoto T, Nakata H, Ohno M, Matu-ura K, Nakagawa E. Bone metastasis of lung cancer. Lung Cancer 18: 31, 1978 (in Japanese).

8) Araki T, Ushio K, Matsumoto T, Kameda N, Akine Y. A autopsy of double cancer (lung cancer and hepatoma) with osteoplastic bone metastasis. Shindan to Tiryou 72: 153, 1984 (in Japanese).

9) Itoh $\mathrm{H}$, Watanabe $\mathrm{A}$, Ooka $\mathrm{T}$. A case of small cell carcinoma of the lung with osteoplastic bone metastasis. Lung Cancer 29: 383, 1989 (in Japanese).

10) Ueno M, Itakura T, Okuno T, Nakai K, Hayashi S. Osteoblastic skull metastasis of lung cancer. Neuro Surg 17: 1077, 1989 (in Japanese).

11) Matsumura $M$, Nishikawa $M$, Ikeda $H$, Okubo $T$, Shibagaki $T$, Kanisawa T. A case of pulmonary adenocarcinoma with marked osteoplastic metastases. Lung Cancer 30: 427, 1990 (in Japanese).

12) Morgan JWM, Adcock KA, Donohue RE. Distribution of skeletal metastases in prostatic and lung cancer, mechanisms of skeletal metastases. Urology 29: 31, 1990.

13) Mundy GR. Mechanisms of osteolytic bone-destruction. Bone 12 (Suppl): s1, 1991.

14) Moseley JM, Kubota M, Diefenbach-Jagger H, et al. Parathyroid hormone-related protein purified from a human lung cancer cell line. Proc Natl Acad Sci USA 84: 5048, 1987.

15) Brandt DW, Burton DW, Gazdar AF, Oie HE, Deftos LJ. All major lung cancer cell types produce parathyroid hormone-like protein: Heterogeneity assessed by high performance liquid chromatography. Endocrinol 129: $2466,1991$. 